\title{
Welcome to NorDiNa 2/2014
}

Welcome to the second issue of NorDiNa in 2014! As a result of the fruitful discussions during the NorDiNa seminar at the NFSUN conference in Helsinki in June, we have now extended the word limit for descriptive contributions to the curriculum development section in NorDiNa from 2000 to 5000 words. All submissions to the curriculum development section are peer reviewed. In this issue we present two contributions to this section (both from Finland): Markku Käpylä presents a phenomenological view of pictures in teaching, and Jari Lavonen and Heidi Krzywacki present an overview of the development of $\mathrm{PhD}$ education in mathematics and science education in Finland.

In Markku Käpylä's contribution, a four-field method based on phenomenological thoughts about human experience and combining factual knowledge with emotions and personal and social meanings is presented, and an example is given from biology. A course unit for using pictures in science teaching was developed from this idea and used in the training of both primary and secondary level teachers. A classification of the teaching functions of pictures is also presented.

Jari Lavonen and Heidi Krzywacki discuss the development of Finnish PhD education in science and mathematics education research over the past 20 years. Doctoral studies seek to develop research knowledge and skills as well as the capability to produce novel scientific knowledge. For the past 20 years, there has been a special focus on improving $\mathrm{PhD}$ education through national-level graduate schools and international collaboration. The recent changes in $\mathrm{PhD}$ education, such as the replacement of doctoral programmes at local universities, are discussed by the authors based on the case of the University of Helsinki.

Jørgen Sjaastad's article entitled "Enhancing measurement in science and mathematics education research through Rasch analysis: Rationale and properties" presents the basic rationale of Rasch theory and seven core properties of Rasch modelling. Examples are provided, drawing on Rasch analysis of data from a survey where students in the 9th grade responded to questions regarding their mathematics competence. The relationship between Rasch theory and classical test theory is commented on. Sjaastad argues that Rasch theory provides science and mathematics education researchers with valuable tools to evaluate the psychometric quality of tests and questionnaires and support the development of these.

The article "Inquiry based dialouge in science classroom" by Ragnhild Löfgren, Klas Johnsson, Jan Schoultz and Lars Domino Østergaard focuses on classroom communication within an inquiry-based science education (IBSE) program. The overall aim of their study was to highlight the ways in which productive and engaging conversations are conducted in the classroom. The authors have analysed 
the work within the unit "The Chemistry of food" and the theme testing of fat in food in grade five and six in a Swedish and a Danish science classroom. Löfgren and colleagues used one video camera and one mp3-player to follow the classroom interaction. The findings indicate that the classroom communication was focused on everyday science content and that the introduction and the summary of the theme were very important for the pupils' possibilities to productive disciplinary engagement.

Mette Nordby and Erik Knain present a study called "Students' dealing with complex issues in video gaming in school science”. In this design-based study the authors have investigated students' encounter with a computer game, Energispillet.no, in school. The study was conducted in a vocational class. In the game the students encounter "texts" that do not convey facts or certain knowledge, but on the contrary entrusts the players to do their own considerations. Based on their own values and attitudes students must jointly make use of knowledge from different disciplines such as natural science, social studies, economics and ethics to make ongoing assessments, argue points of view, and make informed choices during gameplay.

It is increasingly recognised that education plays a key role in addressing human-induced climate change. The ultimate goal of climate change education (CCE) is positive impacts on the climate through both individual and collective actions. The aim of the article "Climate change education: Geography teachers' and ninth-graders' views" by Mikaela Hermans is to investigate geography teachers' and their ninth-graders' views about CCE. Hermans collected data using semi-structured interviews with geography teachers $(\mathrm{N}=13)$ and questionnaires for ninth-graders $(\mathrm{N}=549)$ at eleven secondary schools from all parts of Swedish-speaking Finland. The results show that although the students' attitudes to CCE are positive, it does not supply them with action competence. The geography teachers in this study largely miss the ultimate goal of CCE, pointing at the need for more effort to be made in the process of developing CCE at secondary school.

Birgitte Lund Nielsen presents a study with the title "Students' annotated drawings as a mediating artefact in science teachers' professional development". The study investigates a case study of a teacher examining her 4th graders' conceptual understanding related to factors causing day and night, seasons, and the phases of the Moon both pre- and post-teaching, as a part of participating in the continuous professional development (CPD) project QUEST. The findings pertain to both the 4th graders' conceptual understanding and the teacher's meaning-making when examining the students' annotated drawings and discussing them with colleagues. The spreading of ideas to colleagues is discussed referring to this inquiry as supporting individual but probably not collaborative agency.

In their article entitled "Framing student dialogue and argumentation: Content knowledge development and procedural knowing in SSI inquiry group work", Anne Kristine Byhring and Erik Knain discuss the negotiation of the situated common ground in classroom conversations. Two teacherstudent dialogue sequences with 11th grade students from the Norwegian research project ElevForsk exemplify the negotiation of the situated common ground and the students' deliberation. The analysis examines what goes on in the thematic content, as well as at the interpersonal level of language use. It is suggested by the authors that different framings may complement each other and provide a space for the students' emerging scientific conceptual development as well as for deliberation as a form of emerging procedural knowing.

We would also like to take the opportunity to thank the following colleagues for the excellent work they have done as reviewers for NorDiNa during 2013 and 2014. The work done by our reviewers is essential to ensure the quality of the journal. In fact, without them there would be no journal. 


\begin{tabular}{|c|c|c|}
\hline Maria Åström & Laurence Simmoneaux & Sören Breitinger \\
\hline Torulf Palm & Jardar Cyvin & Per-Olof Wickman \\
\hline Inga-Britt Skogh & Jing-Wen Lin & Kalle Juuti \\
\hline Alex Strømme & Lars Brian Krogh & Per Sund \\
\hline Bodil Sundberg & Jari Lavonen & Irmeli Palmberg \\
\hline Jakob Gyllenpalm & Anita Wallin & Shu-Nu Chang Rundgren \\
\hline Madelen Bodin & Jan Alexis Nielsen & Hafpór Guðjónsson \\
\hline Mats Lindahl & Sharada Gade & Karin Due \\
\hline Claes Malmberg & Karl Göran Karlsson & Merete Sortland \\
\hline Johan Öhman & Fredrik Jeppsson & Margareta Enghag \\
\hline Karin Stolpe & Svein Sjøberg & Gabriel Bladh \\
\hline Mei-Hung Chiu & Niklas Gericke & Allyson MacDonald \\
\hline Christel Persson & Helge Strömdahl & Lena Löfgren \\
\hline lann Lundegård & Jesper Bruun & Britt Jakobson \\
\hline Per Högström & Ingela Bursjöö & Ilkka Ratinen \\
\hline Åsa af Geijerstam & Mona Holmqvist Olander & Lilian Pozzer-Ardenghi \\
\hline Robin Millar & Ragnhild Löfgren & Helena Näs \\
\hline Carl Angell & Ingolfur Johannesson & Berit Bungum \\
\hline Andreas Redfors & Sylvia Benckert & Christine Lindstrøm \\
\hline Olav Prestvik & Jenny Lewis & Eva Nyberg \\
\hline Michal Drechsler & Jens Dolin & Anne Holt \\
\hline Anniken Furberg & Anders Berg & Rolf Vegar Olsen \\
\hline$\varnothing y s t e i n$ Guttersrud & Hanne Møller Andersen & Maria Vetleseter Вøe \\
\hline Camilla Christensson & Karim Hamza & Lena Hansson \\
\hline Sari Havu-Nuutinen & Eila Kyllikki Jelonen & Arja Kaasinen \\
\hline Anne Maarit Karkkainen & Tom Olav Klepaker & Nina Kilbrink \\
\hline Pasi Kaleva Nieminen & Trude Nilsen & Christina Ottander \\
\hline Anders Jidesjö & Jarkko Lampiselkä & Karin Rudsberg \\
\hline Maria Svensson & Bodil Sundberg & Lars Domino $\varnothing$ stergaard \\
\hline Lynn Du Plessis & Eli Munkebye & Jenny Byrne \\
\hline Marianne $\varnothing$ degaard & Christina Kärrquist & Lene M $\emptyset$ ller Madsen \\
\hline Edvin $\varnothing$ stergaard & Klas Sandell & Anna Vikström \\
\hline Veronica Bjurulf & Hannele Cantell & Peter van Marion \\
\hline Jan Sølberg & Oleg Popov & Jesper Haglund \\
\hline
\end{tabular}

We hope you enjoy your reading!

Carl-Johan Rundgren and Are Turmo 